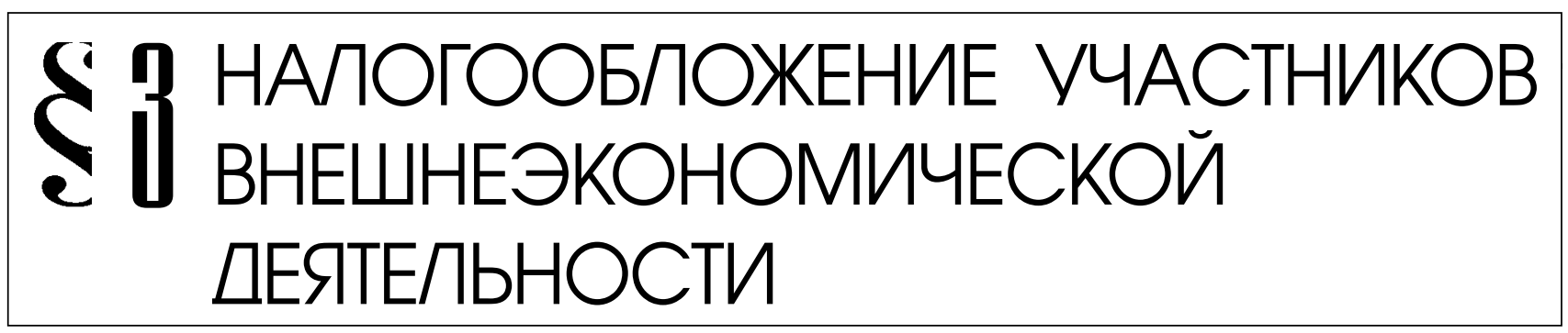

А.Б. Золотарева

\title{
НЕКОТОРЫЕ ПРОБЛЕМЫ ЗАКОНОДАТЕЛЬНОГО РЕГУЛИРОВАНИЯ ВЗЫСКАНИЯ НАЛОГОВ
}

Аннотация: В Постановлении Пленума ВАС РФ от 30.07.2013 № 57 "О некоторых вопросах, возникающих при применении арбитражными судами части первой Налогового кодекса Российской Федерации» взысканию налогов в принудительном порядке посвящен целый раздел. Однако некоторые возникающие на практике проблемы принудительного взыскания остались за рамками внимания Пленума, да и не могут быть решены без поправок в налоговое законодательство. В статье рассматриваются перечисленные в части 3 аннотации аспекты принудительного взыскания налога. В статье используются традиционные для юридических исследований методы сравнительного правового анализа, а также системного анализа. В статье рассматриваются такие аспекты принудительного взыскания налога как: взыскание налоговой задолженности до истечения срока исполнения требования об уплате налога; возможность одновременного взыскания налога за счет денежных средств и иного имущества налогоплательщика; возможность судебного взыскания налоговой задолженности после отмены решения о внесудебном взыскании ввиду допущенных налоговым органом процессуальных нарушений. В статье даются предложения о путях решения выявленных проблем, предлагаемые автором $k$ включению в Основные направления налоговой политики на 2015 год.

Ключевые слова: Взыскание налога, Принудительное взыскание налога, Исполнение налоговой обязанности, Уплата налога, Добровольная уплата налога, Требование уплаты налога, Налоговый кодекс, Налоговое администрирование, Налоги, Налогообложение.

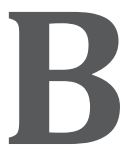

Постановлении Пленума ВАС РФ от 30.07.2013 № 57 «О некоторых вопросах, возникающих при применении арбитражными судами части первой Налогового кодекса Российской Федерации» взысканию налогов в принудительном порядке посвящен целый раздел. Однако некоторые возникающие на практике проблемы принудительного взыскания остались за рамками внимания Пленума, да и не могут быть решены без поправок в налоговое законодательство. Остановимся на некоторых из них.

\section{Взыскание налоговой задолженности до истечения срока исполнения требования об уплате налога}

На первый взгляд, незаконность решения налоговых органов о взыскании задолженности, вынесенного до истечения срока на добровольное исполнение требования об уплате налога, очевидна. П. 3 ст. 46 НК РФ однозначно говорит о том, что «решение о взыскании принимается после истечения срока, установленного в требовании об уплате налога...». Напомним, что этот срок, 
согласно п. 4 ст. 69 НК РФ, составляет в настоящее время 8 дней с даты получения указанного требования, если более продолжительный период для уплаты налога не указан в этом требовании.

Однако правоприменительная практика показывает, что запрет на принудительное взыскание в пределах восьмидневного срока, отведенного для добровольного исполнения требования об уплате налога, соблюдается не всегда. Большинство судов при нарушении налоговыми органами норм п. 3 ст. 46 НК РФ встают на сторону налогоплательщиков и отменяют решение о взыскании ${ }^{1}$. Эта позиция, формально безупречная, зачастую приводит к полной невозможности взыскания задолженности, поскольку в последнее время в судебной практике наметилась тенденция к непризнанию за налоговыми органами права на судебное взыскание задолженности после отмены ранее вынесенного решения о внесудебном взыскании ввиду процессуальных нарушений. Начало этой тенденции положило Постановление Президиума ВАС РФ от 11.05.2010 № 17832/09.

Суть спора заключалась в следующем: по результатам выездной проверки было вынесено решение о начислении недоимки, пеней и о привлечении индивидуального предпринимателя к ответственности. Поскольку предприниматель в добровольном порядке недоимку не погасил, налоговый орган вынес решение о её взыскании, впоследствии отмененное по иску пред-

\footnotetext{
1 См.: Путеводитель по налогам. Энциклопедия спорных ситуаций по части первой Налогового кодекса РФ; Постановления ФАС Восточно-Сибирского округа от 31.08.2012 по делу № А 78-10449/2011, ФАС Московского округа от 23.07.2012 по делу № А40-12689/12-116-24, ФАС Западно-Сибирского округа от 23.04.2010 по делу № А46-21966/2009, ФАС Московского округа от 23.01.2012 по делу № А41-27584/10 и др.
}

принимателя судом (в решении имелись процессуальные недостатки). После этого налоговая инспекция обратилась в суд с иском о взыскании недоимки, так как установленный п. 3 ст. 46 НК шестимесячный срок для ее судебного взыскания не истек. Рассмотрев это дело в порядке надзора, ВАС РФ сделал вывод, что налоговый орган осуществил все этапы принудительного взыскания задолженности, предусмотренные статьями 46 и 47 НК, то есть реализовал свое право на взыскание налогов во внесудебном порядке. Признание недействительным постановления инспекции о взыскании налога за счет иного имущества налогоплательщика, по мнению ВАС, препятствует удовлетворению ее требования о взыскании налога в судебном порядке, так как иное означало бы нарушение равновесия интересов участников отношений, регулируемых законодательством о налогах и сборах Таким образом, ВАС признал не основанными на нормах действующего законодательства выводы нижестоящих судов о том, что налоговые органы имеют право на обращение в суд с заявлением о взыскании задолженности по налоговым обязательствам не только в случае пропуска срока, но и в других случаях нарушения порядка внесудебного взыскания налогов, предусмотренного статьями 46 и 47 Кодекса. Хотя это решение Президиума формально не имеет общеобязательного характера, после его принятия многие суды в аналогичных делах следовали изложенной в нем логике ${ }^{2}$. Разделяя мнение ВАС о нежела-

\footnotetext{
2 См., напр., Постановление ФАС Московского округа от 12.10.2011 по делу № А41-35714/10, Постановление ФАС Поволжского округа от 20.05.2013 по делу № А5521454/2012; Постановление ФАС Поволжского округа от 06.12.2012 по делу № А65-15114/2012; Постановление ФАС Дальневосточного округа от 06.07.2011 № Ф032878/2011 по делу № А73-13536/2010; Постановление
} 
тельности расширительного толкования норм НК в пользу налоговых органов, мы однако считаем целесообразным решить данную проблему на законодательном уровне. На наш взгляд, процессуальные нарушения со стороны налогового органа не должны служить основанием для прекращения налоговой обязанности. В том числе и потому, что такое положение чревато сознательными злоупотреблениями, когда налоговый орган по сговору с налогоплательщиком будет специально допускать процессуальные нарушения в процессе принудительного взыскания ради последующего списания недоимки.

Но вернемся к вопросу о начале процедуры принудительного взыскания до истечения срока добровольного исполнения требования об уплате налога. Как отмечалось выше, большинство судов считают это незаконным. Однако встречаются и исключения из правила.

Например, ФАС Северо-Западного округа в Постановлении от 01.03.2013 по делу № А66-5703/2010 оставил в силе решение о взыскании, вынесенное до истечения срока добровольного исполнения требования об уплате налога, поскольку налогоплательщик не обосновал, как допущенное налоговым органом нарушение повлияло на исполнение налоговой обязанности, и не представил доказательств того, что он имел намерение и мог исполнить эту обязанность добровольно. Часто суды мотивируют свою позицию несущественностью допущенных налоговым органом нарушений. Так, ФАC Западно-Сибирского округа в Постановлении от 21.10.2009 по делу № A27-6222/2009 счел

ФАС Восточно-Сибирского округа от 26.08.2010 по делу № А19-695/10; Постановление ФАС Северо-Кавказского округа от 28.11.2011 по делу № А01-101/2011 и др. несущественным нарушение, выразившееся в начале процедуры принудительного взыскания в последний день срока исполнения требования об уплате налога. Также суд принимал во внимание, что задолженность не была оплачена ни в последний день срока исполнения требования, ни после принятия оспариваемого решения, ни на момент рассмотрения спора в суде. Думается, суды в таких случаях учитывают и тот факт, что отмена решения о взыскании, бесспорного по сути, но принятого с процедурными нарушениями, может привести к невозможности последующего взыскания налога. Суды, занимающие такую позицию, вынуждены идти на нарушение буквы закона, чтобы не причинить ущерб интересам бюджета.

На наш взгляд, вопрос о целесообразности сохранения запрета на принудительное взыскание налога до истечения срока добровольного исполнения требования о его уплате надо решать законодательно, исходя из того, насколько 8-дневная отсрочка принудительного исполнения существенна для обеспечения прав налогоплательщика. Прежде всего, необходимо разобраться, для каких целей эта отсрочка предусмотрена. Если она обеспечивает возможность обжалования налогоплательщиком требования об уплате налога - малейшее нарушение налоговым органом установленного 8-дневного срока недопустимо.

Однако на практике требование об уплате налога почти никогда не обжалуется. Мы употребляем выражение «почти», поскольку требование об уплате налога, как любое другое решение, действие и даже бездействие налогового органа, как и всякого органа власти, может быть обжаловано. Вот только оснований для обжалования требования об уплате налога 
DOI: $10.7256 / 1812-8688.2014 .4 .11957$

При цитировании этой статьи сноска на doi обязательна

\section{Налоги и налогообложение - № 4(118) • 2014}

практически никогда нет ${ }^{3}$. В самом деле, согласно НК такое требование выставляется в двух случаях:

- $\quad$ либо об уплате налога, самостоятельно исчисленного налогоплательщиком;

- $\quad$ либо об уплате недоимки (пени, штрафа) на основании решения о привлечении к ответственности за совершение налогового правонарушения.

Отсутствие оснований для обжалования требования об уплате налога в первом случае очевидно. При наличии же решения о привлечении к ответственности за совершение налогового правонарушения оснований для обжалования также практически нет, поскольку согласно п. 3 ст.101.3 НК требование об уплате недоимки, пеней и штрафа в этом случае направляется только после вступления в силу решения о привлечении к ответственности за налоговое правонарушение. В свою очередь, в соответствии с п.9 ст.101 НК, решение о привлечении к ответственности за совершение налогового правонарушения по общему правилу ${ }^{4}$ вступает в силу по исте-

\footnotetext{
3 Исключение составляют случаи, когда при выставлении требования налоговым органом допущены ошибки (например, в части суммы недоимки). Однако поскольку обжалование такого требования не приостанавливает начала процедуры принудительного взыскания, 8-дневный срок, отделяющий момент выставления требования от начала принудительного взыскания, не имеет принципиального значения. К моменту рассмотрения жалобы по существу задолженность уже может быть взыскана.

4 Исключения из общего правила установлены тем же п.9 ст. 101 НК. Согласно им, решение о привлечении к ответственности за совершение налогового правонарушения и решение об отказе в привлечении к ответственности за совершение налогового правонарушения, вынесенные по результатам рассмотрения материалов выездной налоговой проверки консолидированной группы налогоплательщиков, вступают в силу по истечении одного месяца со дня вручения ответственному участнику этой группы. Решение федерального органа исполнительной власти, уполномоченного по контролю и надзору в области налогов и сборов, о привлечении к ответствен-
}

чении одного месяца со дня вручения лицу, в отношении которого оно вынесено. В случае подачи апелляционной жалобы указанное решение вступает в силу не ранее дня принятия вышестоящим налоговым органом решения по апелляционной жалобе. Таким образом, при наличии решения о привлечении к ответственности за налоговое правонарушение требование об уплате недоимки (пени, штрафа) выставляется либо после истечения месячного срока на обжалование такого решения, либо после его подтверждения вышестоящим налоговым органом.

Следовательно, установленная п. 3 ст. 46 НК 8-дневная отсрочка принудительного исполнения требования об уплате налога не предназначена для обжалования последнего и предоставляется налогоплательщику исключительно для мобилизации средств, необходимых для добровольного исполнения этого требования. Но действительно ли нужен этот срок для подготовки налогоплательщика к добровольному исполнению?

Если речь идет о налоговом обязательстве, исчисленном самим налогоплательщиком, то отсрочка исполнения требования налогового органа о погашении такого обязательства по сути - необоснованная льгота налогоплательщику, не исполнившему налоговое обязательство. В самом деле, налогоплательщик сам исчислил сумму налога, подал декларацию, осведомлен о сроке исполнения обязательства, однако вовремя его не исполнил, чем вынудил налоговый орган выставлять соответствующее требование. Нужно ли в данной ситу-

\footnotetext{
ности за совершение налогового правонарушения или об отказе в привлечении к ответственности за совершение налогового правонарушения вступает в силу со дня его вручения лицу, в отношении которого было вынесено соответствующее решение (его представителю).
} 
DOI: $10.7256 / 1812-8688.2014 .4 .11957$

При цитировании этой статьи сноска на dоі обязательна

Налогообложение участников внешнеэкономической деятельности

ации предоставлять налогоплательщику еще 8 дней «законной» отсрочки исполнения уже просроченного обязательства? На наш взгляд, нет, в том числе и потому, что такая дополнительная просрочка исполнения обязательства никак не наказывается. Штрафы в данном случае к налогоплательщику не применяются ${ }^{5}$, пени также не увеличиваются - их размер фиксирован и составляет за каждый день просрочки одну трехсотую ставки рефинансирования Банка России от неуплаченной суммы налога или сбора. Поскольку указанный размер пени, как правило, несколько ниже средневзвешенной ставки банков по рублевым кредитам ${ }^{6}$, у налогоплательщика возникает возможность безнаказанно кредитоваться за счет бюджета, откладывая исполнение налогового обязательства до получения соответствующего требования.

Более того, 8-дневный срок, отделяющий момент получения требования об уплате задолженности от начала ее принудительного взыскания, позволяет недобросовестному налогоплатель-

\footnotetext{
Согласно п.19 Постановления Пленума ВАС РФ от 30.07.2013 № 57 «О некоторых вопросах, возникающих при применении арбитражными судами части первой Налогового кодекса Российской Федерации» бездействие налогоплательщика, выразившееся исключительно в неперечислении в бюджет указанной в налоговой декларации или налоговом уведомлении суммы налога, не образует состав правонарушения, установленного статьей 122 НК РФ.

6 Так, с 14.09.2012 г. по настоящее время ставка рефинансирования Центробанка составляет 8,25\% годовых (Указание ЦБ РФ от 13 сентября 2012 г. № 2873-У), соответственно размер пени - 9,9 \% годовых. При этом, по информации Центробанка России, средневзвешенная ставка российских кредитных организаций (без учета ОАО «Сбербанк России») по рублевым кредитам нефинансовым организациям на срок до 1 года составила в октябре 2012 года 10,1\%, а к декабрю 2012 выросла до 10,4\% годовых (http://www.cbr.ru/statistics/priNot. aspx?file=b_sector/credits_deposits_12.htm\&pid=cdps_46 782\&sid=itm_48233)
}

щику вывести активы, за счет которых это взыскание может осуществляться. Предотвратить такое развитие событий налоговый орган не может, поскольку обеспечительные меры в виде приостановления операций налогоплательщика по его счетам в банке или ареста имущества в данном случае неприменимы ${ }^{7}$.

Ситуация меняется, когда требование об уплате недоимки, пеней и штрафа выставляется в порядке привлечения к ответственности за совершение налогового правонарушения. Как говорилось выше, при обжаловании решения о привлечении к ответственности оно вступает в силу с момента подтверждения вышестоящим налоговым органом. Хотя и в данном случае необходимость уплаты недоимки, пеней и штрафов при проигрыше спора не является для налогоплательщика неожиданностью, в этой ситуации предоставление отсрочки исполнения более оправдано. Риск использования налогоплательщиком этой отсрочки для выведения активов, за счет которых может осуществляться взыскание, в данном случае достаточно низок, поскольку в соответствии с п.10 ст.101 НК с момента принятия решения о привлечении к ответственности за совершение налогового правонарушения до его исполнении допускаются обеспечительные меры.

Но наиболее важным аргументом в пользу сохранения 8-дневного срока добровольного исполнения требования об уплате недоимки, образовавшейся вследствие налогового правонарушения, явля-

\footnotetext{
7 Так, в соответствии с п.2 ст.76 НК решение о приостановлении операций по счетам в банке может быть принято лишь после неисполнения налогоплательщиком требования об уплате налога, пеней или штрафа, а арест имущества (согласно п.1 ст.77 НК) используется лишь для обеспечения исполнения решения о взыскании налога, пеней и штрафов.
} 
ется следующее положение п.4 ст.69 НК: «в случае, если размер недоимки, выявленный в результате налоговой проверки, позволяет предполагать факт совершения нарушения законодательства о налогах и сборах, содержащего признаки преступления, в направляемом требовании должно содержаться предупреждение об обязанности налогового органа в случае неуплаты сумм недоимки, пеней и штрафов в полном объеме в установленный срок направить материалы в следственные органы для решения вопроса о возбуждении уголовного дела». Оставим в стороне вопрос о том, является ли целесообразным освобождение от уголовной ответственности по данному основанию в принципе, с учетом того, что погашение недоимки после выявления налогового правонарушения нельзя признать добровольным ${ }^{8}$. Но пока такое основание освобождения от уголовной ответственности существует, оно должно быть в равной мере доступно для всех налогоплательщиков. Между тем, принудительное взыскание недоимки до истечения установленного законом срока исполнения требования о ее уплате может лишить налогоплательщика возможности освобождения от уголовной ответственности путем «добровольного» погашения недоимки. На это можно возразить, что и после принудительного взыскания у налогоплательщика остается возможность уплатить ту же сумму добровольно до истечения установленного срока. Однако при крупной сумме недоимки налогоплательщик может оказаться не в состоянии в 8-дневный срок собрать двукратную сумму долга. Из этого вытекает недопустимость

\footnotetext{
8 Позиция автора по этому вопросу изложена в работе Налоговое администрирование. Основные итоги реформы. Золотарева А. Б., Киреева А.В., Корниенко Н.Ю. М.: ИЭПП, 2008.
}

отмены срока добровольного исполнения требований, выставленных по результатам привлечения налогоплательщика к ответственности за совершение налогового правонарушения.

С учетом сказанного, можно предложить два варианта внесения изменений в Налоговый кодекс в целях решения рассматриваемой проблемы:

а) Сохранить 8-дневный срок добровольного исполнения требования об уплате налога (сбора, пени, штрафа) только применительно к требованиям, выставленным в порядке привлечения налогоплательщика к ответственности за совершение налогового правонарушения. Одновременно следует уточнить в НК, что нарушение этого срока является безусловным основанием для отмены решения о взыскании налога.

Применительно же к требованиям о взыскании задолженности, самостоятельно исчисленной налогоплательщиком, этот срок отменить, что равносильно отказу от выставления требований об уплате задолженности, самостоятельно исчисленной налогоплательщиком. Такая задолженность может взыскиваться по процедурам, предусмотренным статьями 46 и 47 НК, немедленно по наступлении срока уплаты налога.

б) Менее предпочтительный вариант состоит в том, чтобы сохранить 8-дневный срок добровольного исполнения любых требований об уплате налога (сбора, пени, штрафа) - касающихся уплаты задолженности, как самостоятельно исчисленной налогоплательщиком, так и составляющей предмет налогового правонарушения. Однако при этом необходимо предпринять меры против искусственного затягивания налогоплательщиком срока погашения самостоятельно исчисленной им налоговой 
обязанности. Среди таких мер можно рассматривать:

- повышение общего размера пени или только размера пени, начисляемых на сумму задолженности, задекларированной налогоплательщиком. Оба решения не лишены недостатков. Повышение общего размера пени нежелательно по ряду причин. Во-первых, во многих случаях до налоговой проверки налогоплательщик может не сознавать наличия у него налоговой задолженности, а следовательно - не иметь возможности ее погашения. Во-вторых, размер пени несущественно ниже ставки банковского процента по кредитам, причем неуплата недоимки, выявленной налоговыми органами, помимо пени карается штрафом. Повышение исключительно размера пени, начисляемых на сумму задолженности, задекларированную налогоплательщиком, также нежелательно, поскольку пени, по логике НК, играют компенсаторную, а не карательную роль. А значит, их размер не должен дифференцироваться в зависимости от вида налогового нарушения.

- принимая во внимание недостатки указанного выше варианта, более предпочтительным представляется установление самостоятельной ответственности за правонарушение, заключающееся в несвоевременном исполнении налоговой обязанности, самостоятельно исчисленной налогоплательщиком. Санкции за такое правонарушение могут выражаться в штрафе, исчисляемом, как и пени, в процентах от суммы задолженности за каждый день просрочки. Фактически речь идет о повышающем коэффициенте к пени, размер которых, с одной стороны, должен быть существенно ниже штрафов, взимаемых за неуплату налога по ст.122 НК, а с другой, - должен повышать плату за пользование бюджетными средствами до уровня не ниже средневзвешенного процента по банковским кредитам, тем самым исключая заинтересованность налогоплательщика в затягивании погашения задолженности.

\section{Риски двукратного взыскания недоимки}

Как известно, Налоговый кодекс разграничивает процедуры взыскания налога за счет средств налогоплательщика на счетах в банках и его электронных денег (по статье 46) и иного имущества налогоплательщика (по статье 47) 9 . По замыслу законодателя, взыскание налога за счет «иного имущества» возможно только при отсутствии или недостаточности у налогоплательщика необходимых для этого безналичных средств (п.7 ст.46). Однако Кодекс не предусматривает никакого «периода ожидания» при переходе от взыскания задолженности за счет безналичных средств налогоплательщика к взысканию за счет иного имущества, которое осуществляет судебный пристав-исполнитель. Фактически постановление о взыскании задолженности может быть направлено судебному приставу-исполнителю уже на следующий

\footnotetext{
9 По вопросам взыскания налога см. также Туранцева Ю. Истина в суде: принудительное взыскание задолженности за счет имущества налогоплательщика // Новая бухгалтерия. 2013. № 11. С. 122-143; Гаврилов В. О некоторых вопросах, возникающих при применении арбитражными судами части первой НК РФ // Налоговый вестник: комментарии к нормативным документам для бухгалтеров. 2013. № 11. С. 10-14. Снегирев А.Г. Взыскание налога за счет имущества // Промышленность: бухгалтерский учет и налогообложение. 2013. № 5. С. 57-66.
} 
день после выставления инкассового поручения банку, если таковое не было незамедлительно исполнено. При этом инкассовое поручение банку не подлежит отзыву, так как абз. 2 п. 6 ст. 46 НК РФ обязывает банк при отсутствии возможности немедленного исполнения этого поручения производить списание налоговой задолженности по мере поступления средств на счета налогоплательщика. Таким образом, одна и та же недоимка может одновременно взыскиваться двумя различными субъектами (банком и судебным приставом-исполнителем), действия которых не скоординированы, что создает риск ее двукратного взыскания.

Этот риск относительно невелик в ситуации, когда первоначальное взыскание произведено судебным приставом, поскольку п.4.1 ст.46 НК обязывает налоговые органы отзывать неисполненные инкассовые поручения при исполнении иным образом обязанности по уплате налогов. Однако вторичное взыскание суммы недоимки банком может быть осуществлено в промежуток времени, необходимый для извещения приставом-исполнителем налогового органа об успешном окончании исполнительного производства ${ }^{10}$ и отзыва налоговым органом инкассового поручения банку, тем более, что срок такого отзыва НК не закреплен.

Вероятность вторичного взыскания суммы недоимки выше, когда первоначальное взыскание было осуществлено банком, несмотря на то что пп.5 п.2 ст.43

\footnotetext{
10 В соответствии с п. 6 ст. 47 Федерального закона «Об исполнительном производстве» копия постановления судебного пристава-исполнителя об окончании исполнительного производства направляется в суд, другой орган или должностному лицу, выдавшим исполнительный документ, не позднее дня, следующего за днем вынесения этого постановления.
}

Федерального закона «Об исполнительном производстве» обязывает приставаисполнителя прекратить исполнительное производство в случае отмены или признания недействительным исполнительного документа, на основании которого это производство возбуждено. Однако НК не предусматривает не только срока, в течение которого налоговый орган должен известить судебного пристава-исполнителя об отмене постановления о взыскании налога за счет имущества налогоплательщика в случае погашения недоимки за счет средств на его банковских счетах, но и вообще - необходимости отмены такого постановления в указанном случае.

Можно предложить два подхода к решению данной проблемы. Первый подход, в наибольшей степени обеспечивающий интересы налогоплательщика, заключается в том, чтобы исключить возможность одновременного взыскания одной и той же недоимки двумя различными субъектами. Для этого потребуется установить в п. 6 ст. 46 НК РФ срок, который отводится на исполнение поручения о взыскании налога с банковских счетов налогоплательщика, до истечения которого взыскание на иное имущество по статье 47 НК РФ обращено быть не может. Одновременно с этим следует:

- у уточнить порядок наложения ареста на имущество налогоплательщика, чтобы не допустить его сокрытия от налогообложения. Согласно п. 3 ст. 77 НК РФ в действующей редакции арест имущества может быть применен только для обеспечения взыскания налога, пеней и штрафов за счет имущества налогоплательщика-организации в соответствии со статьей 47 НК РФ. То есть до тех пор, пока налоговый орган не вынес решение о взыскании недоимки за 
счет имущества налогоплательщика и ожидает исполнения решения о ее взыскании за счет безналичных средств, налогоплательщик может принимать меры к сокрытию имущества;

- дополнить ст. 46 НК РФ указанием, что при начале процедуры взыскания налога за счет иного имущества налогоплательщика по статье 47 НК поручение на списание средств с его банковских счетов, ранее выставленное налоговым органом, подлежит отмене.

Очевидные недостатки этого решения заключаются в удлинении срока и снижении вероятности полного взыскания недоимки. Удлинение срока связано с тем, что процедура взыскания по ст.47 обычно предполагает необходимость реализации имущества налогоплательщика с торгов. Снижение вероятности полного взыскания недоимки обусловлено как удлинением срока взыскания, так и рисками недостаточности (или недостаточной ликвидности) имущества налогоплательщика для полного погашения недоимки. С учетом этих недостатков более предпочтительным представляется другой подход, который, снижая риски двукратного взыскания недоимки, достаточно обеспечивает интересы бюджета. Этот подход состоит в том, чтобы при сохранении возможности параллельного взыскания недоимки за счет средств на банковских счетах и иного имущества налогоплательщика улучшить координацию действий банков, налоговых органов и приставов-исполнителей. Для реализации этого подхода потребуется:

- Закрепить в п.4.1 ст.46 НК срок отзыва налоговым органом неисполненных банками инкассовых поручений, который должен составлять не более 1-2 рабочих дней с момента получения налоговым органом от пристава-исполнителя постановления об окончании исполнительного производства ввиду полного взыскания задолженности. В случае неполного погашения задолженности в ходе исполнительного производства налоговый орган в тот же срок должен одновременно с отзывом предыдущего инкассового поручения довести до банков новое поручение с уточненной суммой задолженности с учетом произведенного взыскания;

- Предусмотреть обязанность налогового органа отменить (изменить) постановление о взыскании налога за счет имущества налогоплательщика в соответствии со ст.47 НК в случае полного (или частичного) погашения недоимки за счет средств на его банковских счетах, и установить максимальный срок для выполнения этой обязанности, который также не должен превышать 2 дней с момента получения соответствующей информации от банка.

\section{Библиография:}

1. Налоговый кодекс Российской Федерации (часть первая) от 31.07.1998 № 146-ФЗ: принят Гос. Думой Федер. Собр. Рос. Федерации 16 июля 1998 г.: одобр. Советом Федерации Федер. Собр. Рос. Федерации 17 июля 1998 г. // «Собрание законодательства РФ», № 31, 03.08.1998, ст. 3824 .

2. Федеральный закон «Об исполнительном производстве»: принят Гос. Думой Федер. Собр. Рос. Федерации 14 сентября 2007 г.: одобр. Советом Федерации Федер. Собр. Рос. Федерации 14 сентября 2007 г. // «Собрание законодательства РФ», , 08.10.2007, № 41, ст. 4849. 
3. Постановление Пленума ВАС РФ от 30.07 .2013 № 57 «0 некоторых вопросах, возникающих при применении арбитражными судами части первой Налогового кодекса Российской Федерации» // Документ опубликован не был. Доступ из справ. - правовой системы «КонсультантПлюс»

4. Постановление Президиума ВАС РФ от 11.05.2010 № 17832/09// Документ опубликован не был. Доступ из справ. - правовой системы «КонсультантПлюс».

5. Постановление ФАС Восточно-Сибирского округа от 31.08.2012 по делу № A7810449/2011// Документ опубликован не был. Доступ из справ. - правовой системы «КонсультантПлюс».

6. Постановление ФАС Московского округа от 23.07.2012 по делу № A40-12689/12-11624// Документ опубликован не был. Доступ из справ. - правовой системы «КонсультантПлюс».

7. Постановление ФАС Западно-Сибирского округа от 23.04.2010 по делу № A4621966/2009// Документ опубликован не был. Доступ из справ. - правовой системы «КонсультантПлюс».

8. Постановление ФАС Московского округа от 23.01.2012 по делу № A41-27584/10 // Документ опубликован не был. Доступ из справ. - правовой системы «КонсультантПлюс».

9. Постановление ФАС Северо-Западного округа от 01.03.2013 по делу № А665703/2010// Документ опубликован не был. Доступ из справ. - правовой системы «КонсультантПлюс».

10. Постановление ФАС Западно-Сибирского округа от 21.10.2009 по делу № А27$6222 / 2009 / /$ Документ опубликован не был. Доступ из справ. - правовой системы «КонсультантПлюс».

11. Постановление ФАС Московского округа от 12.10.2011 по делу № A41-35714/10// Документ опубликован не был. Доступ из справ. - правовой системы «КонсультантПлюс».

12. Постановление ФАС Поволжского округа от 20.05.2013 по делу № A55-21454/2012// Документ опубликован не был. Доступ из справ. - правовой системы «КонсультантПлюс».

13. Постановление ФАС Поволжского округа от 06.12.2012 по делу № A65-15114/2012// Документ опубликован не был. Доступ из справ. - правовой системы «КонсультантПлюс».

14. Постановление ФАС Дальневосточного округа от 06.07.2011 № Ф03-2878/2011 по делу № A73-13536/2010// Документ опубликован не был. Доступ из справ. — правовой системы «КонсультантПлюс».

15. Постановление ФАС Восточно-Сибирского округа от 26.08.2010 по делу № А19695/10// Документ опубликован не был. Доступ из справ. - правовой системы «КонсультантПлюс».

16. Постановление ФАС Северо-Кавказского округа от 28.11.2011 по делу № А01101/2011// Документ опубликован не был. Доступ из справ. - правовой системы «КонсультантПлюс».

17. Указание ЦБ РФ от 13 сентября 2012 г. № 2873-У // «Вестник Банка России», № 55, 19.09.2012. 
18. Гаврилов В. О некоторых вопросах, возникающих при применении арбитражными судами части первой НК РФ // Налоговый вестник: комментарии к нормативным документам для бухгалтеров. 2013. № 11. С. 10-14.

19. Налоговое администрирование. Основные итоги реформы. Монография в 3 томах. Золотарева А. Б., Киреева А.В., Корниенко Н.Ю. - М.: ИЭПП, 2008. — 786 с.

20. Путеводитель по налогам. Энциклопедия спорных ситуаций по части первой Налогового кодекса РФ// Документ опубликован не был. Доступ из справ. - правовой системы «КонсультантПлюс».

21. Снегирев А.Г. Взыскание налога за счет имущества // Промышленность: бухгалтерский учет и налогообложение. 2013. № 5. С. 57-66.

22. Туранцева Ю. Истина в суде: принудительное взыскание задолженности за счет имущества налогоплательщика // Новая бухгалтерия. 2013. № 11. С. 122-143.

23. Ефремова Т.А. Налоговое администрирование в России: предпосылки становления и особенности функционирования // NB: Финансовое право и управление. - 2013. 2. - C. 1-23. DOI: 10.7256/2306-4234.2013.2.622. URL: http://www.e-notabene.ru/flc/ article_622.html

24. Балаева Д.А., Моргоева А.Х. Налоговое администрирование: взгляд в будущее // Налоги и налогообложение. - 2014. - 2. - C. 174-183. DOI: 10.7256/18128688.2014.2.11361.

25. Ефремова Т.А. Налоговое администрирование в России: предпосылки становления и особенности функционирования // NB: Финансовое право и управление. - 2013. 2. - C. 1-23. DOI: 10.7256/2306-4234.2013.2.622. URL: http://www.e-notabene.ru/flc/ article_622.html

26. Кинсбурская В.А. Ответственность налогоплательщика за непредставление налоговой декларации: спорные вопросы правоприменительной практики // NB: Финансовое право и управление. - 2013. - 1. - C. 17-48. DOI: 10.7256/2306-4234.2013.1.558. URL: http://www.e-notabene.ru/flc/article_558.html

27. Агузарова Ф.С. Некоторые вопросы модернизации налоговой системы Российской Федерации // NB: Финансовое право и управление. - 2013. - 2. C. 24-44. DOI: 10.7256/2306-4234.2013.2.629. URL: http://www.e-notabene.ru/flc/ article_629.html

28. Мусаева X.M. О проблемах и перспективах развития налогового федерализма в условияхмодернизации экономики РФ // NB: Финансовое право и управление. - 2013. 1. - C. 49-63. DOI: 10.7256/2306-4234.2013.1.476. URL: http://www.e-notabene.ru/flc/ article_476.html

29. Аринин Е.А. Теоретические аспекты организационно - правового механизма налогообложения в Российской Федерации. // NB: Финансовоеправо и управление. - 2013. 4. - C. 1 - 29. DOI: 10.7256/2306-4234.2013.4.855. URL: http://www.e-notabene.ru/flc/ article_855.html

30. Казьмин А.Г., Оробинская И.В. Анализ поступления налогов в бюджеты областей Центрально-Чернозёмного района // NB: Финансовое право и управление. - 2012. 1. - C. 156-211. URL: http://www.e-notabene.ru/flc/article_358.html 


\section{References:}

1. Nalogovyi kodeks Rossiiskoi Federatsii (chast’ pervaya) ot 31.07.1998 № 146-FZ: prinyat Gos. Dumoi Feder. Sobr. Ros. Federatsii 16 iyulya 1998 g.: odobr. Sovetom Federatsii Feder. Sobr. Ros. Federatsii 17 iyulya 1998 g. // “Sobranie zakonodatel’stva RF”, № 31, 03.08.1998, st. 3824.

2. Federal'nyi zakon «Ob ispolnitel'nom proizvodstve»: prinyat Gos. Dumoi Feder. Sobr. Ros. Federatsii 14 sentyabrya 2007 g.: odobr. Sovetom Federatsii Feder. Sobr. Ros. Federatsii 14 sentyabrya 2007 g. // "Sobranie zakonodatel'stva RF”, 08.10.2007, № 41, st. 4849.

3. Postanovlenie Plenuma VAS RF ot 30.07.2013 № 57 “O nekotorykh voprosakh, voznikayushchikh pri primenenii arbitrazhnymi sudami chasti pervoi Nalogovogo kodeksa Rossiiskoi Federatsii" // Dokument opublikovan ne byl. Dostup iz sprav. — pravovoi sistemy «Konsul'tantPlyus»

4. Postanovlenie Prezidiuma VAS RF ot 11.05.2010 № 17832/09// Dokument opublikovan ne byl. Dostup iz sprav. — pravovoi sistemy "Konsul'tantPlyus".

5. Postanovlenie FASVostochno-Sibirskogo okruga ot 31.08.2012 po delu № A78-10449/2011// Dokument opublikovan ne byl. Dostup iz sprav. - pravovoi sistemy "Konsul'tantPlyus".

6. Postanovlenie FAS Moskovskogo okruga ot 23.07.2012 po delu № A40-12689/12-116-24// Dokument opublikovan ne byl. Dostup iz sprav. — pravovoi sistemy "Konsul'tantPlyus".

7. Postanovlenie FAS Zapadno-Sibirskogo okruga ot 23.04.2010 po delu № A46-21966/2009// Dokument opublikovan ne byl. Dostup iz sprav. - pravovoi sistemy "Konsul'tantPlyus".

8. Postanovlenie FAS Moskovskogo okruga ot 23.01.2012 po delu № A41-27584/10 // Dokument opublikovan ne byl. Dostup iz sprav. - pravovoi sistemy "Konsul'tantPlyus".

9. Postanovlenie FAS Severo-Zapadnogo okruga ot 01.03.2013 po delu № A66-5703/2010// Dokument opublikovan ne byl. Dostup iz sprav. - pravovoi sistemy "Konsul'tantPlyus".

10. Postanovlenie FAS Zapadno-Sibirskogo okruga ot 21.10.2009 po delu № A27-6222/2009// Dokument opublikovan ne byl. Dostup iz sprav. — pravovoi sistemy "Konsul'tantPlyus".

11. Postanovlenie FAS Moskovskogo okruga ot 12.10.2011 po delu № A41-35714/10// Dokument opublikovan ne byl. Dostup iz sprav. - pravovoi sistemy "Konsul'tantPlyus".

12. Postanovlenie FAS Povolzhskogo okruga ot 20.05.2013 po delu № A55-21454/2012// Dokument opublikovan ne byl. Dostup iz sprav. - pravovoi sistemy "Konsul'tantPlyus".

13. Postanovlenie FAS Povolzhskogo okruga ot 06.12.2012 po delu № A65-15114/2012// Dokument opublikovan ne byl. Dostup iz sprav. - pravovoi sistemy "Konsul'tantPlyus".

14. Postanovlenie FAS Dal'nevostochnogo okruga ot 06.07.2011 № F03-2878/2011 po delu № A73-13536/2010// Dokument opublikovan ne byl. Dostup iz sprav. — pravovoi sistemy "Konsul'tantPlyus".

15. Postanovlenie FAS Vostochno-Sibirskogo okruga ot 26.08 .2010 po delu № A19-695/10// Dokument opublikovan ne byl. Dostup iz sprav. - pravovoi sistemy "Konsul'tantPlyus".

16. Postanovlenie FAS Severo-Kavkazskogo okruga ot 28.11.2011 po delu № A01-101/2011// Dokument opublikovan ne byl. Dostup iz sprav. - pravovoi sistemy "Konsul'tantPlyus".

17. Ukazanie TsB RF ot 13 sentyabrya 2012 g. № 2873-U // "Vestnik Banka Rossii”, № 55, 19.09.2012.

18. Gavrilov V. O nekotorykh voprosakh, voznikayushchikh pri primenenii arbitrazhnymi sudami chasti pervoi NK RF // Nalogovyi vestnik: kommentarii k normativnym dokumentam dlya bukhgalterov. 2013. № 11. S. 10-14. 
19. Nalogovoe administrirovanie. Osnovnye itogi reformy. Monografiya v 3 tomakh. Zolotareva A. B., Kireeva A.V., Kornienko N.Yu. - M.: IEPP, 2008. - 786 s.

20. Putevoditel' po nalogam. Entsiklopediya spornykh situatsii po chasti pervoi Nalogovogo kodeksa RF// Dokument opublikovan ne byl. Dostup iz sprav. - pravovoi sistemy "Konsul'tantPlyus".

21. Snegirev A.G. Vzyskanie naloga za schet imushchestva // Promyshlennost': bukhgalterskii uchet i nalogooblozhenie. 2013. № 5. S. 57-66.

22. Turantseva Yu. Istina v sude: prinuditel'noe vzyskanie zadolzhennosti za schet imushchestva nalogoplatel’shchika // Novaya bukhgalteriya. 2013. № 11. S. 122-143.

23. Efremova T.A. Nalogovoe administrirovanie v Rossii: predposylki stanovleniya i osobennosti funktsionirovaniya // NB: Finansovoe pravo i upravlenie. - 2013. - 2. - C. 1-23. DOI: 10.7256/2306-4234.2013.2.622. URL: http://www.e-notabene.ru/flc/article_622.html

24. Balaeva D.A., Morgoeva A.Kh. Nalogovoe administrirovanie: vzglyad v budushchee // Nalogi i nalogooblozhenie. - 2014. - 2. - C. 174-183. DOI: 10.7256/1812-8688.2014.2.11361.

25. Efremova T.A. Nalogovoe administrirovanie v Rossii: predposylki stanovleniya i osobennosti funktsionirovaniya // NB: Finansovoe pravo i upravlenie. - 2013. - 2. - C. 1-23. DOI: 10.7256/2306-4234.2013.2.622. URL: http://www.e-notabene.ru/flc/article_622.html

26. Kinsburskaya V.A. Otvetstvennost' nalogoplatel'shchika za nepredstavlenie nalogovoi deklaratsii: spornye voprosy pravoprimenitel'noi praktiki // NB: Finansovoe pravo i upravlenie. - 2013. - 1. - C. 17-48. DOI: 10.7256/2306-4234.2013.1.558. URL: http://www.enotabene.ru/flc/article_558.html

27. Aguzarova F.S. Nekotorye voprosy modernizatsii nalogovoi sistemy Rossiiskoi Federatsii // NB: Finansovoe pravo i upravlenie. - 2013. - 2. - C. 24-44. DOI: 10.7256/23064234.2013.2.629. URL: http://www.e-notabene.ru/flc/article_629.html

28. Musaeva Kh.M. 0 problemakh i perspektivakh razvitiya nalogovogo federalizma v usloviyakhmodernizatsii ekonomiki RF // NB: Finansovoe pravo i upravlenie. - 2013. — 1. C. 49-63. DOI: 10.7256/2306-4234.2013.1.476. URL: http://www.e-notabene.ru/flc/article_476.html

29. Arinin E.A. Teoreticheskie aspekty organizatsionno - pravovogo mekhanizma nalogooblozheniya v Rossiiskoi Federatsii. // NB: Finansovoe pravo i upravlenie. - 2013. - 4. C. 1-29. DOI: 10.7256/2306-4234.2013.4.855. URL: http://www.e-notabene.ru/flc/article_855.html

30. Kaz'min A.G., Orobinskaya I.V. Analiz postupleniya nalogov v byudzhety oblastei Tsentral'noChernozemnogo raiona // NB: Finansovoe pravo i upravlenie. - 2012. - 1. - C. 156-211. URL: http://www.e-notabene.ru/flc/article_358.html 